\title{
Phosphate addition to phosphorus-deficient Baltic Sea plankton communities benefits nitrogen-fixing Cyanobacteria
}

\author{
Emil Vahtera ${ }^{1,2, *}$, Riitta Autio ${ }^{1,3}$, Hermanni Kaartokallio ${ }^{1,3}$, Maria Laamanen ${ }^{1,4}$ \\ ${ }^{1}$ Department of Biological Oceanography, Finnish Institute of Marine Research, PO Box 2, 00561 Helsinki, Finland \\ ${ }^{2}$ Present address: Woods Hole Oceanographic Institution, Redfield 332 MS\#32, Woods Hole, Massachusetts 02543, USA \\ ${ }^{3}$ Present address: Finnish Environment Institute, PO Box 140, 00251 Helsinki, Finland \\ ${ }^{4}$ Present address: Helsinki Commission (Baltic Marine Environment Protection Commission), \\ Katajanokanlaituri 6 B, 00160 Helsinki, Finland
}

\begin{abstract}
The effect of single nutrient additions (ammonia or phosphate) on the biomass and phosphorus dynamics of natural Baltic Sea phytoplankton bloom communities dominated by nitrogen-fixing Cyanobacteria was studied. The aim was to elucidate bloom-time phosphorus deficiency characteristics of the community. In addition, the intention was to study the effect of an increased phosphate supply on phosphate uptake in different size fractions and to test the hypothesis of increased phosphate supply favoring large nitrogen-fixing Cyanobacteria during general phosphate deficiency. Based on specific phosphate uptake affinity and specific alkaline phosphatase activity, the bloom communities showed varying degrees of phosphorus deficiency. The bulk of phosphate uptake was dominated by the 8 to $20 \mu \mathrm{m}$ size fraction. However, if the community initially showed signs of phosphorus deficiency, phosphate addition increased the relative amount of phosphate taken up by the size fraction dominated by nitrogen-fixing Cyanobacteria. The 2 main bloom-forming filamentous diazotrophic species, Aphanizomenon sp. (considered non-toxic in the Baltic Sea) and Nodularia spumigena (toxic), showed differing levels of phosphorus deficiency. $N$. spumigena constantly had a higher percentage of the population expressing alkaline phosphatase activity, as indicated by enzyme-labeled fluorescence assays. Approximately one-fifth of added phosphate was estimated to be taken up by the diazotrophic Cyanobacteria during phosphorus deficiency.
\end{abstract}

KEY WORDS: Nitrogen-fixing Cyanobacteria · Phosphate uptake · Baltic Sea · Aphanizomenon sp. Nodularia spumigena

Resale or republication not permitted without written consent of the publisher

\section{INTRODUCTION}

During thermally stratified conditions, intrusions of deeper water alter surface layer nutrient ratios and cause species selection in Baltic Sea phytoplankton communities (Kononen et al. 1996, Vahtera et al. 2005). Quasi-stationary salinity fronts that run along the Gulf of Finland axis in the western gulf are frequently observed. Here, frontal upwelling events and horizontal advection of water affect stratification conditions and nutrient concentrations, which again affect the phytoplankton community composition (Kononen et al.
1996, Moisander et al. 1997, Pavelson et al. 1997). The northern coast of the Gulf of Finland is an area of intense coastal upwelling (Myrberg \& Andrejev 2003). Coastal upwelling events affect the surface layer in a similar way as frontal upwelling, but with a more pronounced effect on surface layer temperatures. Temperatures may decrease by $10^{\circ} \mathrm{C}$ within hours, and phosphate and ammonium concentrations can increase up to 4 - and 10-fold, respectively (Haapala 1994).

The occurrence of diazotrophic Cyanobacteria (cyanobacteria that possess the capacity to fix dissolved atmospheric nitrogen) is generally promoted by 
low nitrogen to phosphorus $(\mathrm{N}: \mathrm{P})$ ratios and high $\mathrm{P}$ concentrations, with some species seemingly indifferent to P supply during the growth period (Smith 1983, Kangro et al. 2007). The main bloom-forming filamentous diazotrophic species in the Baltic Sea, Nodularia spumigena Mertens ex Bornet \& Flahault 1886, and Aphanizomenon sp. Morren ex Bornet et Flahault 1886, typically bloom during conditions deficient in dissolved nutrients, in areas south of approximately $62^{\circ} \mathrm{N}$ (see Fig. 1). During these conditions, their growth and $\mathrm{N}_{2}$-fixation are promoted, to varying degrees, by the additions of inorganic $\mathrm{P}$ and/or trace elements and dissolved organic matter (Stal et al. 1999, Moisander et al. 2003, Stolte et al. 2006), while the phytoplankton productivity of non- $\mathrm{N}_{2}$-fixing species generally experiences N limitation (Granéli et al. 1990, Tamminen \& Andersen 2007).

The pelagic phytoplankton community of the Baltic Sea undergoes a typical annual succession for coastal temperate regions. A spring bloom of dinoflagellates and diatoms is initiated by increased solar irradiation after ice break and stratification of the upper water column (Wasmund et al. 1998). The spring bloom in the Gulf of Finland and in coastal regions of the Baltic is typically N limited (Kivi et al. 1993, Kuosa et al. 1997, Tamminen \& Andersen 2007), and dissolved inorganic $\mathrm{N}$ (DIN) is exhausted from the upper mixed layer by the end of April. Various amounts of dissolved inorganic and organic $\mathrm{P}$ are left over after the spring bloom in the upper mixed layer (e.g. Larsson et al. 2001, Nausch et al. 2008), constituting an excess of $P$ beyond the requirements of the non $\mathrm{N}_{2}$-fixing phytoplankton that dominate the community during spring and early summer. During summer, the dissolved inorganic N:P ratio has been below the Redfield ratio of 16:1 at least since the late 1970s in the northern Baltic Proper (Suikkanen et al. 2007). The calculated excess $P$, based on winter DIN and dissolved inorganic P (DIP) concentrations and a consumption of nutrients in the Redfield ratio of 16:1 during spring, has shown an increasing trend at least since the beginning of the 1990s (Laanemets et al. 2006). Late winter phosphate concentrations and subsequent excess $\mathrm{P}$ in various forms (biologically available dissolved inorganic and organic P forms), is hypothesized to eventually fuel the growth of a summer community often dominated by diazotrophic Cyanobacteria (Larsson et al. 2001, Janssen et al. 2004). Cellular P storage and processes that regenerate inorganic $\mathrm{P}$ in the surface layer during thermal stratification have also been noted to be important regulative factors for bloom formation of diazotrophic Cyanobacteria (Larsson et al. 2001, Lignell et al. 2003).
Blooms of diazotrophic Cyanobacteria have been observed to initiate in frontal regions and upwelled water (Kononen et al. 1996, Vahtera et al. 2005), and the frequency and intensity of pre-bloom upwelling events have been noted to be important factors promoting Aphanizomenon sp. blooms (Lips \& Lips 2008).

We conducted a field experiment to investigate the nutrient limitation characteristics of diazotrophic cyanobacterial bloom communities during the bloom period in the Gulf of Finland and northern Baltic Proper and the effects of altered nutrient supply stoichiometry on phosphate uptake by a size fractionated community. Series of $48 \mathrm{~h}$ incubations with single pulsed nutrient addition treatments of ammonia or phosphate were made. The phytoplankton community biomass (as chlorophyll [chl] a and particulate P), alkaline phosphatase activity, and size fractionated community phosphate uptake were measured. In addition, species-specific P deficiency of the diazotrophic Cyanobacteria was studied with an enzyme-labeled fluorescence (ELF) technique.

\section{MATERIALS AND METHODS}

Description of study sites and experiments. Our study was conducted in July 2003 along a northeast to southwest transect from the central Gulf of Finland to the northern Baltic Proper (Fig. 1), encompassing a salinity gradient in the upper $5 \mathrm{~m}$ layer (5.4 to 6.6). In 2003, the Gulf of Finland was characterized by a moderate cyanobacterial bloom dominated by Aphanizomenon sp. (Lips \& Lips 2008). A homogeneous upper mixed layer approximately $5 \mathrm{~m}$ deep was observed at all experimental stations, and the surface water temperature ranged between 18 and $20^{\circ} \mathrm{C}$.

Three geographically distinct experimental stations were visited. The first station was revisited after $7 \mathrm{~d}$. The experimental stations are hereafter denoted Expt A (14 July, western Gulf of Finland), B (16 July, central Gulf of Finland), C (21 July, Baltic Proper), and D (23

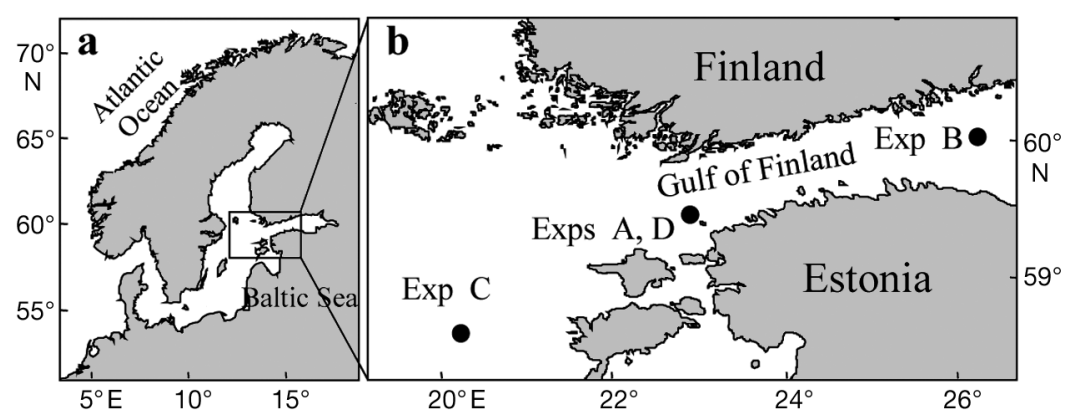

Fig. 1. Baltic Sea (a) and study area (b) located in the central part of the Baltic Sea. The 4 experimental stations (A to D) are marked with dots in (b) 
July, western Gulf of Finland). Sea water for the experimental treatments was acquired using a 301 sampler. Samples were taken from a depth interval of 2 to $3 \mathrm{~m}$.

The experimental treatments consisted of (1) a control (no addition), (2) ammonium $\left(\mathrm{NH}_{4}^{+}\right)$addition, and (3) phosphate $\left(\mathrm{PO}_{4}{ }^{3-}\right)$ addition (hereafter denoted as Control, $+\mathrm{N}$, and $+\mathrm{P}$ treatments, respectively). $\mathrm{N}$ was added as ammonium $\left(8.0 \mu \mathrm{mol}^{-1}\right)$ and $\mathrm{P}$ as phosphate $(0.5 \mu \mathrm{mol}$ $\left.\mathrm{l}^{-1}\right)$. The final nutrient concentrations in the treatments mimicked natural concentrations occurring below the seasonal thermocline during the cruise. Immediately after the nutrient additions, two $14 \mathrm{l}$ aliquots of each treatment were transferred to duplicate experimental units (acid-washed transparent polyethylene containers) that were incubated for $48 \mathrm{~h}$ on deck in large water baths at ambient sea water temperature. Samples for determination of particulate $\mathrm{P}$, alkaline phosphatase, chl $a$, soluble reactive $\mathrm{P}$ (SRP), dissolved inorganic nitrogen (DIN) concentrations and ELF assays were acquired on 3 occasions: 1 or 2, 24 and $48 \mathrm{~h}$ from the start of the experiment from the 141 experimental units. In order to determine orthophosphate turnover times $\left(T_{\mathrm{t}} ; \mathrm{h}\right)$, duplicate $250 \mathrm{ml}$ samples were taken on 3 occasions $(2,24$ and $46 \mathrm{~h}$ ) from the 141 experimental units and incubated on deck for 30 to $120 \mathrm{~min}$ in $500 \mathrm{ml}$ acid-washed glass flasks.

To determine size fractionated $\mathrm{P}$ incorporation, $500 \mathrm{ml}$ experimental units receiving the same nutrient additions as the 141 experimental units were incubated in the on deck flow-through pool for $48 \mathrm{~h}$ in an acid washed $1 \mathrm{l}$ polycarbonate flasks. These $500 \mathrm{ml}$ experimental units were sampled at 4 occasions at 2, 8, 25 and $46 \mathrm{~h}$ from the start of the experiments.

Solar irradiation intensity in the on deck flowthrough pools was reduced to levels equaling irradiation intensities at approximately 2 to $5 \mathrm{~m}$ depth

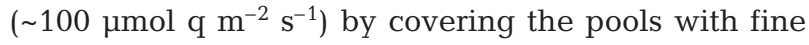
black mesh.

Analytical methods. For phytoplankton identification and quantification, $250 \mathrm{ml}$ samples were preserved with acid Lugol's solution and processed using the Utermöhl (1958) technique. Cyanobacterial filaments were counted as $100 \mu \mathrm{m}$ segments and other phytoplankton as single cells or colonies. Biovolumes were estimated according to HELCOM guidelines (Olenina et al. 2006) with the PhytoWin software.

For analysis of chl a concentrations, duplicate $200 \mathrm{ml}$ samples were filtered on GF/F (Whatman) glass fiber filters, which were extracted at room temperature for $24 \mathrm{~h}$ in $10 \mathrm{ml}$ of $96 \%$ ethanol. Chl a concentrations were measured using a Perkin-Elmer LS-2B fluorometer, after filtration through GF/F filters for the removal of interfering particles (HELCOM 1988). The fluorometer was calibrated with pure chl a (Sigma Chemical).

SRP and DIN concentrations were determined from single $10 \mathrm{ml}$ water samples according to the guidelines for the second stage of the Baltic Monitoring Programme (Grasshoff et al. 1983, HELCOM 1983). The analysis detection limits were $0.05,0.1,0.06$, and $0.25 \mu \mathrm{mol} \mathrm{l}^{-1}$ for $\mathrm{SRP}, \mathrm{NO}_{3}, \mathrm{NO}_{2}$ and $\mathrm{NH}_{4}$, respectively. Particulate nutrients were analyzed from single $250 \mathrm{ml}$ samples filtered on pre-combusted and acid washed GF/F (Whatman) filters according to the same protocol as for SRP after boiling the filter in $50 \mathrm{ml}$ of persulfate solution.

Samples for determination of the orthophosphate turnover times $\left(T_{\mathrm{t}}\right)$ were allowed to acclimate in the water baths used for incubation for at least $30 \mathrm{~min}$ before addition of carrier free ${ }^{33} \mathrm{PO}_{4}{ }^{3-}$ (20000 to 50000 DPM) to each bottle. Using a 12-hole Micropore filtration manifold, $T_{\mathrm{t}}$ was measured by filtration of $10 \mathrm{ml}$ sub-samples onto $25 \mathrm{~mm}, 0.2 \mu \mathrm{m}$ pore size polycarbonate membrane filters (Whatman) at 3 time points. The filtration intervals ranged from 10 to $120 \mathrm{~min}$, depending on expected turnover times based on SRP concentrations. The samples were filtered under low suction $(<20 \mathrm{kPa}$ to reduce error caused by breakage of fragile cells) until completely dry and then transferred to liquid scintillation vials with immediate addition of scintillation liquid (Instagel). The incorporated ${ }^{33} \mathrm{PO}_{4}{ }^{3-}$ was assayed with liquid scintillation techniques (Wallac RackBeta), and all results were corrected for decay time of ${ }^{33} \mathrm{P}$. Formalin killed triplicate samples (500 $\mu$ l formalin $10 \mathrm{ml}^{-1}$ sample), treated similarly to live samples, were used to estimate the amount of abiotic adsorption. The use of formalin may cause damage to cell walls and thus leakage of P from cells. $T_{\mathrm{t}}$ was calculated according to Thingstad et al. (1993), where a consumed fraction of added radioactive label $r(t)$ is assumed to follow the theoretical expression $r(t)=$ $\left(1-\mathrm{e}^{-t / T_{\mathrm{t}}}\right)$. The incubation time following the addition of the isotope is denoted by $t(\mathrm{~h})$. $T_{\mathrm{t}}$ can then be determined with 1 time point measurement by solving the equation for $T_{\mathrm{t}}=t /-\ln (1-r(t))$. $T_{\mathrm{t}}$ was estimated 3 times during each of the 4 experiments, at the beginning $(2 \mathrm{~h}$ after nutrient additions) and after 24 and $46 \mathrm{~h}$, except for Expt D, when only 1 estimate was made after $2 \mathrm{~h}$.

Relative incorporation of ${ }^{33} \mathrm{P}$ in 3 different size fractions $(0.2-8,8-20$, and $>20 \mu \mathrm{m})$ was measured by filtration onto membrane filters of different pore sizes $(0.2 \mu \mathrm{m}, 8 \mu \mathrm{m})$ after incubation and subsequent subtraction of relevant fractions. The $>20 \mu \mathrm{m}$ size fraction was obtained by filtration of samples through a $20 \mu \mathrm{m}$ mesh, after which the sample was filtered onto a $0.2 \mu \mathrm{m}$ pore size membrane filter. To obtain the $>20 \mu \mathrm{m}$ fraction, the value of the sample that was first filtered through the $20 \mu \mathrm{m}$ mesh was subtracted from the value of the total $>0.2 \mu \mathrm{m}$ fraction. Pre-killed sample results were not subtracted from the size fractionation samples to account for abiotic adsorption of ${ }^{33} \mathrm{PO}_{4}{ }^{3-}$ onto Cyanobacteria aggregate associated sur- 
faces. Abiotic adsorption can be of considerable importance and can affect $\mathrm{P}$ transfer between size fractions due to a more static nature of the surface adsorbed fraction (Sañudo-Wilhelmy et al. 2004, Fu et al. 2005) and generally low ingestion of the large aggregateforming Cyanobacteria by zooplankton (Sellner et al. 1994, Engström et al. 2001, Hambright et al. 2001). Thus, we wanted to include the abiotically adsorbed fraction in our results. Further, abiotic adsorption was measured only from the total, $>0.2 \mu \mathrm{m}$ sample. Thus, it is not possible to give estimates of abiotic adsorption for the different size fractions.

Based on $T_{\mathrm{t}}$, size-fractionated phosphate uptake, and size-fractionated P biomass estimates $(0.2-20 \mu \mathrm{m}$ and $>20 \mu \mathrm{m}$, data not shown), the specific affinity for phosphate $\left(\alpha, 1 \mu\right.$ mol- $\left.\mathrm{P}^{-1} \mathrm{~h}^{-1}\right)$ uptake was calculated according to Thingstad \& Rassoulzadegan (1999) for 2 size fractions $(0.2-20 \mu \mathrm{m}$ and $>20 \mu \mathrm{m})$. The specific affinity for phosphate uptake, $\alpha$, is estimated by dividing the fraction of radioactive label incorporated in a size fraction by the product of the turnover time $\left(T_{\mathrm{t}}\right)$ and estimated $\mathrm{P}$ biomass $(B), \alpha=f / T_{\mathrm{t}} B$.

Total alkaline phosphatase activity (APA) was measured according to Petterson (1980) with modifications as described by Kononen et al. (1993). Triplicate $4 \mathrm{ml}$ samples were incubated at $20^{\circ} \mathrm{C}$ in the dark in acidwashed test tubes. 4-methylumbelliferyl-phosphate (MUF-P) was used as the substrate at a final saturating concentration of $125 \mu \mathrm{mol} \mathrm{l^{-1 }}$. The assays were run for 60 min with measurements every $15 \mathrm{~min}$, and the results were checked for linearity. Fluorescence readings were made with a Jasco 750 spectrofluorometer at an excitation wavelength of $365 \mathrm{~nm}$ and an emission wavelength of $460 \mathrm{~nm}$. Fluorescence units were calibrated with MUF standard solutions over the range from 0.01 to $1 \mathrm{\mu mol} \mathrm{l}^{-1}$, and the fluorescence intensity increase in the samples was used to calculate the potential APA given as $\mu$ mol MUF-P hydrolyzed $\mathrm{h}^{-1}$. APA was normalized to particulate $\mathrm{P}$ to obtain biomass specific APA (SAPA) and account for bacterial and zooplankton biomass.

Species SAPA of diazotrophic Cyanobacteria was studied using the ELF technique (González-Gil et al. 1998). The ELF 97 endogenous phosphatase detection kit (Invitrogen E6600) was used on samples concentrated on a $20 \mu \mathrm{m}$ nylon mesh that was folded into a funnel. The sample was transferred from the mesh with a pipette into $1.5 \mathrm{ml}$ centrifuge tubes, by first washing the mesh with the filtrate to flush all of the sample to the bottom of the funnel. The samples were centrifuged at $1000 \times g$ for $5 \mathrm{~min}$, after which the supernatant was removed without disturbing the pellet. The pellet was incubated in the dark for $30 \mathrm{~min}$ in $500 \mu \mathrm{l}$ of $70 \%$ ethanol, after which the centrifugation procedure was repeated and the supernatant removed.
A $70 \mu \mathrm{l}$ mix of the ELF-P substrate and buffer solution (1:20) was added on the pellet, and the sample was incubated in the dark for another $30 \mathrm{~min}$. The incubation was stopped by repeatedly washing the sample with filtered $(0.2 \mu \mathrm{m})$ and autoclaved seawater. Samples were stored in 200 to $300 \mu \mathrm{l}$ of filtered seawater in the dark at $5^{\circ} \mathrm{C}$. Samples were counted within 1 mo of the preparation using epifluorescence microscopy (Leitz Aristoplan) using a UV excitation filter set with a long pass emission filter (excitation/emission: 340 to $380 / 425 \mathrm{~nm})$. The total amount of filaments and the amount of filaments showing ELF alcohol (ELFA, the product of ELF-P hydrolysis) fluorescence were counted. In total, at least 100 filaments were counted.

Statistical analyses. Mixed model repeated measures analyses (PROC MIXED) of the Statistical Analysis System (SAS V8.02, SAS Institute) were used to test for mean differences in particulate $\mathrm{P}$ concentration, SAPA, chl a concentration, size fractionated phosphate uptake, and relative amount of filaments showing ELFA fluorescence. We tested for the main effect of treatment and time and for the interaction of these terms on the measured parameters separately for each experiment for all variables except phosphate uptake and ELFA. Differences in phosphate uptake were tested for the main effects of treatment for each size fraction separately. Differences in relative amounts of filaments showing ELFA fluorescence were tested for the main effects of species and treatment and the interaction of species and treatment. An autoregressive covariance structure was used, and the experimental unit was used as the within-subject factor and the treatment as the between-subject factor. Logarithm transformations were applied where necessary to ensure a normal distribution of model residuals. When the criteria for parametric tests could not be met by transformations, we used a Kruskal-Wallis non-parametric test to test for differences between treatments separately for each time point.

\section{RESULTS}

\section{Phytoplankton community composition and chl a biomass}

The phytoplankton community standing stock biomass at the beginning of the experiments was dominated by diazotrophic Cyanobacteria in all cases. In Expt A, 64\% of total wet weight biomass consisted of Aphanizomenon sp. (635 $\mathrm{mg} \mathrm{m}^{-3}$ ), whereas the contribution of Nodularia spumigena $\left(4.6 \mathrm{mg} \mathrm{m}^{-3}\right)$ was very modest $(<1 \%)$. The biomass of haptophytes of the genus Chrysochromulina constituted $9 \%\left(96 \mathrm{mg} \mathrm{m}^{-3}\right)$ of the total wet weight biomass. In Expt B, Aphani- 
zomenon sp. (866 $\mathrm{mg} \mathrm{m}^{-3}$ ) contributed $62 \%$ and $N$. spumigena (110 $\mathrm{mg} \mathrm{m}^{-3}$ ) $8 \%$ to total wet weight biomass. Chrysochromulina spp. biomass (165 $\mathrm{mg} \mathrm{m}^{-3}$ ) comprised $11 \%$ of the total wet weight biomass. At the beginning of Expt $\mathrm{C}$, in contrast to the previous experiments, N. spumigena biomass (929 $\mathrm{mg} \mathrm{m}^{-3}$ ) represented $55 \%$ of total wet weight biomass and Aphanizomenon sp. represented $14 \%\left(238 \mathrm{mg} \mathrm{m}^{-3}\right)$ of total wet weight biomass. Pyramimonas spp. (Prasinophycea; $238 \mathrm{mg} \mathrm{m}^{-3}$ ) and the diatom Nitzschia paleacea $\left(140 \mathrm{mg} \mathrm{m}^{-3}\right.$ ) comprised 14 and $8 \%$ of total biomass, respectively. Expt D, which was the same sampling station as Expt A, showed a decrease in Aphanizomenon sp. (217 $\mathrm{mg} \mathrm{m}^{-3}$ ) biomass from the previous sampling to $45 \%$ and a slight increase of N. spumigena $\left(35 \mathrm{mg} \mathrm{m}^{-3}\right)$ biomass to $7 \%$ of total wet weight biomass. Chrysochromulina spp. (57 $\mathrm{mg} \mathrm{m}^{-3}$ ) comprised $11 \%$ of the total wet weight biomass.
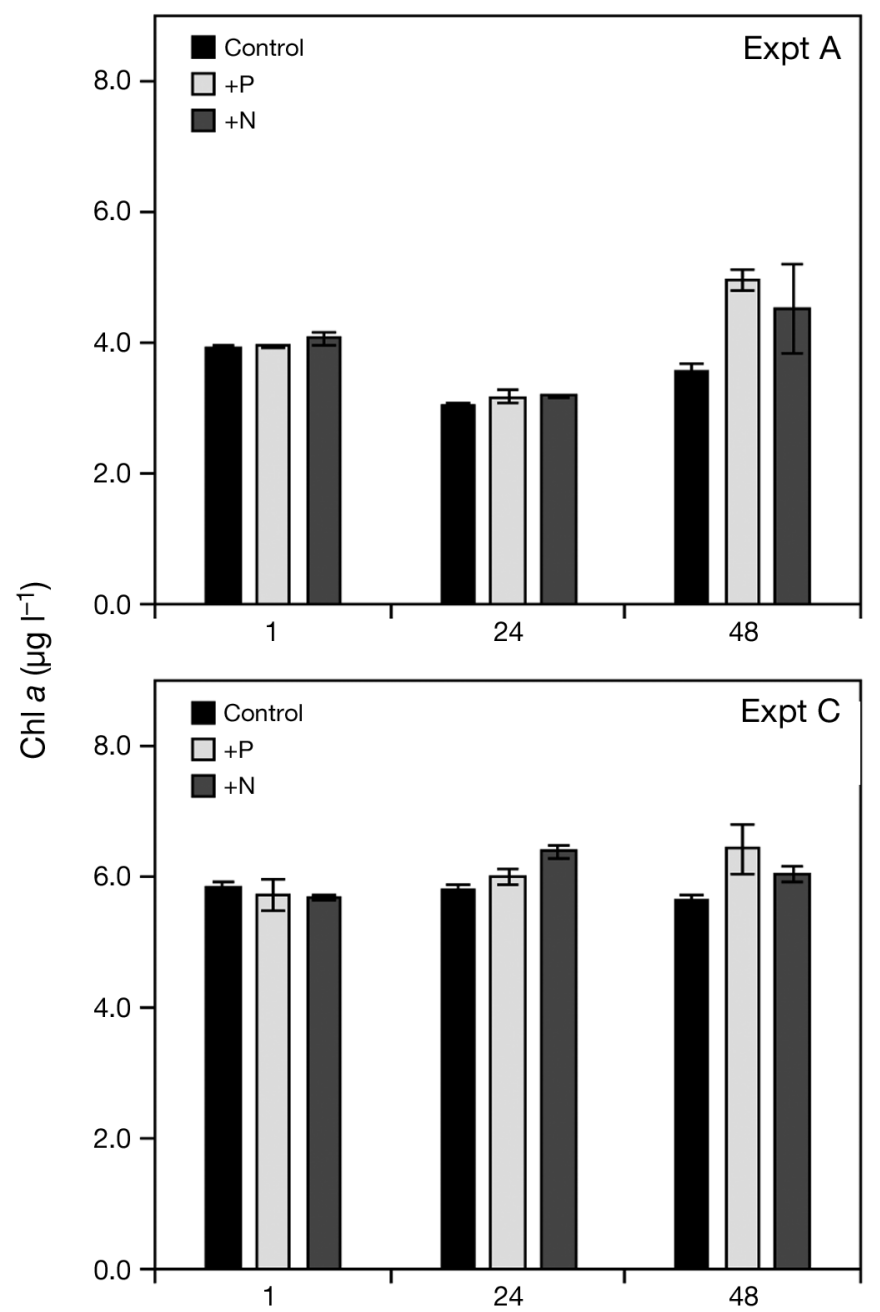

Chl a concentrations varied between the experiments, with Expts B and C having on average the highest total chl a concentrations (Fig. 2). Treatment effects in Expt A were non-significant. However, the concentrations changed significantly during the experiment, and the model interaction term was significant (Table 1) indicating differing slopes, i.e. differing responses through time, for the treatments. The Control treatment showed a declining chl a concentration during the $48 \mathrm{~h}$ incubation; this is in contrast to the increasing trend observed during the $+\mathrm{P}$ and $+\mathrm{N}$ treatments (Fig. 2). All treatments showed an initial decline in chl a biomass after $24 \mathrm{~h}$ of incubation. Expt B showed clear and significant treatment effects and a significant interaction term (Table 1). Chl a concentrations declined in the Control and $+\mathrm{N}$ treatments in a similar manner, whereas the $+\mathrm{P}$ treatment showed slightly increasing concentrations. Expt $\mathrm{C}$ showed a
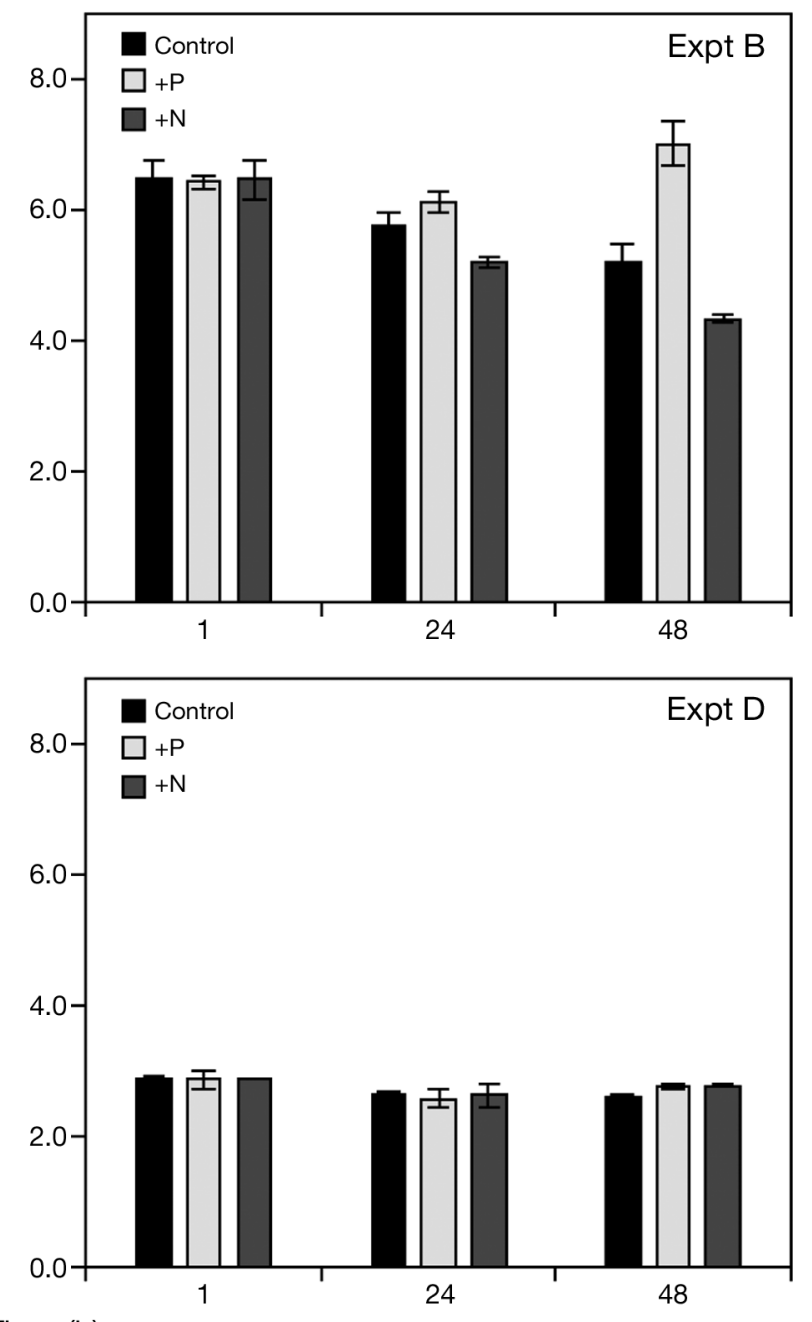

Time (h)

Fig. 2. Average chlorophyll a $\left(\mathrm{chl}\right.$ a) concentrations $\left(\mu \mathrm{g} \mathrm{l} \mathrm{l}^{-1}\right)$ in the experimental units in Expts A to D during the $48 \mathrm{~h}$ incubations. Error bars denote $\mathrm{SD}, \mathrm{n}=2$ (duplicate treatments). $+\mathrm{P}$ and $+\mathrm{N}$ indicate the phosphate- and ammonium-addition treatments, respectively 
Table 1. Repeated measures mixed model results for type III tests for fixed effects for the dependent variables: chlorophyll (chl) $a$, particulate phosphorus (P), particulate $\mathrm{P}$ specific alkaline phosphatase activity (SAPA). Analyses for particulate $\mathrm{P}$ in Expt C were not done due to inability to fulfill parametric test assumptions. Num df: numerator degrees of freedom, den df: denominator degrees of freedom

\begin{tabular}{|c|c|c|c|c|c|c|c|c|c|c|c|c|c|c|c|c|}
\hline & \multicolumn{4}{|c|}{$\longrightarrow$ Expt A } & \multicolumn{4}{|c|}{$\longrightarrow$ Expt B } & \multicolumn{4}{|c|}{ - Expt C- } & \multicolumn{4}{|c|}{- Expt D } \\
\hline & $\begin{array}{c}\text { Num } \\
\text { df }\end{array}$ & $\begin{array}{c}\text { Den } \\
\mathrm{df}\end{array}$ & F & $\mathrm{p}>F$ & $\underset{\mathrm{df}}{\mathrm{Num}}$ & $\begin{array}{c}\text { Den } \\
\text { df }\end{array}$ & $F$ & $\mathrm{p}>F$ & $\begin{array}{c}\mathrm{Num} \\
\mathrm{df}\end{array}$ & $\begin{array}{c}\text { Den } \\
\text { df }\end{array}$ & $F$ & $\mathrm{p}>F$ & $\underset{\mathrm{df}}{\mathrm{Num}}$ & $\begin{array}{c}\text { Den } \\
\mathrm{df}\end{array}$ & F & $\mathrm{p}>F$ \\
\hline \multicolumn{17}{|l|}{ Chl a } \\
\hline Treatment & 2 & 3 & 7.45 & 0.07 & 2 & 3 & 21.14 & 0.02 & 2 & 3 & 4.25 & 0.13 & 2 & 3 & 0.23 & 0.81 \\
\hline Day & 2 & 6 & 100.01 & $<0.01$ & 2 & 6 & 44.35 & $<0.01$ & 2 & 6 & 7.15 & 0.03 & 2 & 6 & 16.00 & $<0.01$ \\
\hline Interaction & 4 & 6 & 6.07 & 0.03 & 4 & 6 & 28.61 & $<0.01$ & 4 & 6 & 6.41 & 0.02 & 4 & 6 & 1.28 & 0.37 \\
\hline \multicolumn{17}{|c|}{ Particulate $\mathbf{P}$} \\
\hline Treatment & 2 & 3 & 1.68 & 0.32 & 2 & 3 & 11.78 & 0.04 & & & & & 2 & 3 & 179.87 & $<0.01$ \\
\hline Day & 1 & 3 & 3.34 & 0.16 & 2 & 6 & 37.02 & $<0.01$ & & & & & 2 & 6 & 2.42 & 0.17 \\
\hline Interaction & 2 & 3 & 0.81 & 0.52 & 4 & 6 & 9.69 & $<0.01$ & & & & & 4 & 6 & 1.53 & 0.31 \\
\hline \multicolumn{17}{|l|}{ SAPA } \\
\hline Treatment & 2 & 3 & 3.31 & 0.17 & 2 & 3 & 17.67 & 0.02 & 2 & 3 & 33.66 & $<0.01$ & 2 & 3 & 118.86 & $<0.01$ \\
\hline Day & 1 & 3 & 1.74 & 0.32 & 2 & 6 & 8.32 & 0.02 & 2 & 6 & 11.18 & $<0.01$ & 2 & 6 & 8.44 & 0.02 \\
\hline Interaction & 2 & 3 & 0.79 & 0.56 & 4 & 6 & 12.9 & $<0.01$ & 4 & 6 & 8.84 & 0.01 & 4 & 6 & 6.37 & 0.02 \\
\hline
\end{tabular}

slight increase in the $+\mathrm{P}$ treatments and an initial increase and subsequent slight decrease in chl a concentrations in the $+\mathrm{N}$ treatment. The Control treatment showed stable chl a concentrations. Treatment effects were non-significant, but the differences in the response of treatments through time were mirrored by a significant interaction term (Table 1), similar to Expt A. Expt D showed no significant treatment effects. However, significant differences of chl a concentrations between days were observed (Table 1).

\section{Particulate and dissolved nutrient concentrations}

Particulate P concentrations showed generally clear treatment effects (Fig. 3), albeit with occasional variability. In Expt A, no significant trends were discernible (Table 1), and SRP concentrations at the beginning and the end of the experiment indicated no net uptake of phosphate, except for the $+\mathrm{N}$ treatment (Table 2). DIN concentrations indicated net uptake of $\mathrm{N}$ in the Control and $+\mathrm{P}$ treatments.

Expt B showed significant treatment effects for particulate $\mathrm{P}$ concentrations, and a significant interaction term (Table 1). Particulate P had overall increasing concentrations in the $+\mathrm{P}$ treatment and more stable concentrations in the Control unit with a slight increase at the end of the experiment. The $+\mathrm{N}$ treatment showed an initial increase with a subsequent decrease by the end of the experiment (Fig. 3). The results are consistent with the SRP concentrations that show net uptake in the $+\mathrm{P}$ and Control treatments but no decrease in the $+\mathrm{N}$ treatment (Table 2). In the $+\mathrm{P}$ treatment, average $( \pm \mathrm{SD})$ particulate $\mathrm{P}$ concentrations increased from $0.43 \pm 0.03$ to $0.94 \pm 0.02 \mathrm{\mu mol} \mathrm{l}^{-1}$, nearly equaling the phosphate addition of $0.50 \mathrm{\mu mol}^{-1}$. DIN concentrations indicated a net uptake of $\mathrm{N}$ only in the Control treatment, although large variation was observed.

Expt C showed a similar pattern as Expt B in the development of particulate P (Fig. 3). We were unable to normalize the variable residuals, thus a non-parametric Kruskal-Wallis test was used for statistical analysis. The Control and $+\mathrm{N}$ treatments showed rather stable particulate $\mathrm{P}$ concentrations, and the $+\mathrm{P}$ treatment displayed a marked average $( \pm \mathrm{SD})$ increase from $0.57 \pm 0.01$ to $0.99 \pm 0.03 \mu \mathrm{mol} \mathrm{l}^{-1}$, being close to the added concentration of $0.5 \mu \mathrm{mol} \mathrm{l}^{-1}$. By the end of the experiment, the treatment effects were significant $\left(\chi^{2}=7.8, \mathrm{df}=2, \mathrm{p}>\chi^{2} 0.02\right)$. SRP concentrations in the $+\mathrm{P}$ treatment showed net uptake of phosphate, whereas the SRP concentration did not change in the $+\mathrm{N}$ treatment. The Control and $+\mathrm{N}$ treatments had SRP concentrations at and below the detection limit $\left(0.05 \mu \mathrm{mol} \mathrm{l}^{-1}\right)$ of the method used (Table 2). DIN concentrations showed a net uptake of $\mathrm{N}$ in the $+\mathrm{N}$ treatment. The $+\mathrm{P}$ treatment also showed net uptake, despite low concentrations of DIN. The Control treatments had low and variable concentrations.

Expt D showed a significant treatment effect for particulate $\mathrm{P}$ (Table 1). Concentrations were fairly stable during the experiment in all treatments. In the $+P$ treatment, particulate $\mathrm{P}$ concentrations were approximately 0.15 to $0.20 \mu \mathrm{mol} \mathrm{l^{-1 }}$ higher than in the Control and $+\mathrm{N}$ treatments, respectively. SRP concentrations indicated net uptake of phosphate in the $+\mathrm{P}$ treatment. The $+\mathrm{N}$ and Control treatments had similar concentrations at the beginning and end of the experiment due to very low concentrations and high variability (Table 2). The $+\mathrm{N}$ treatment showed a decrease in DIN, indicating a net uptake of N. DIN concentrations decreased in the Control and $+\mathrm{P}$ treatments as well, despite low concentrations. 

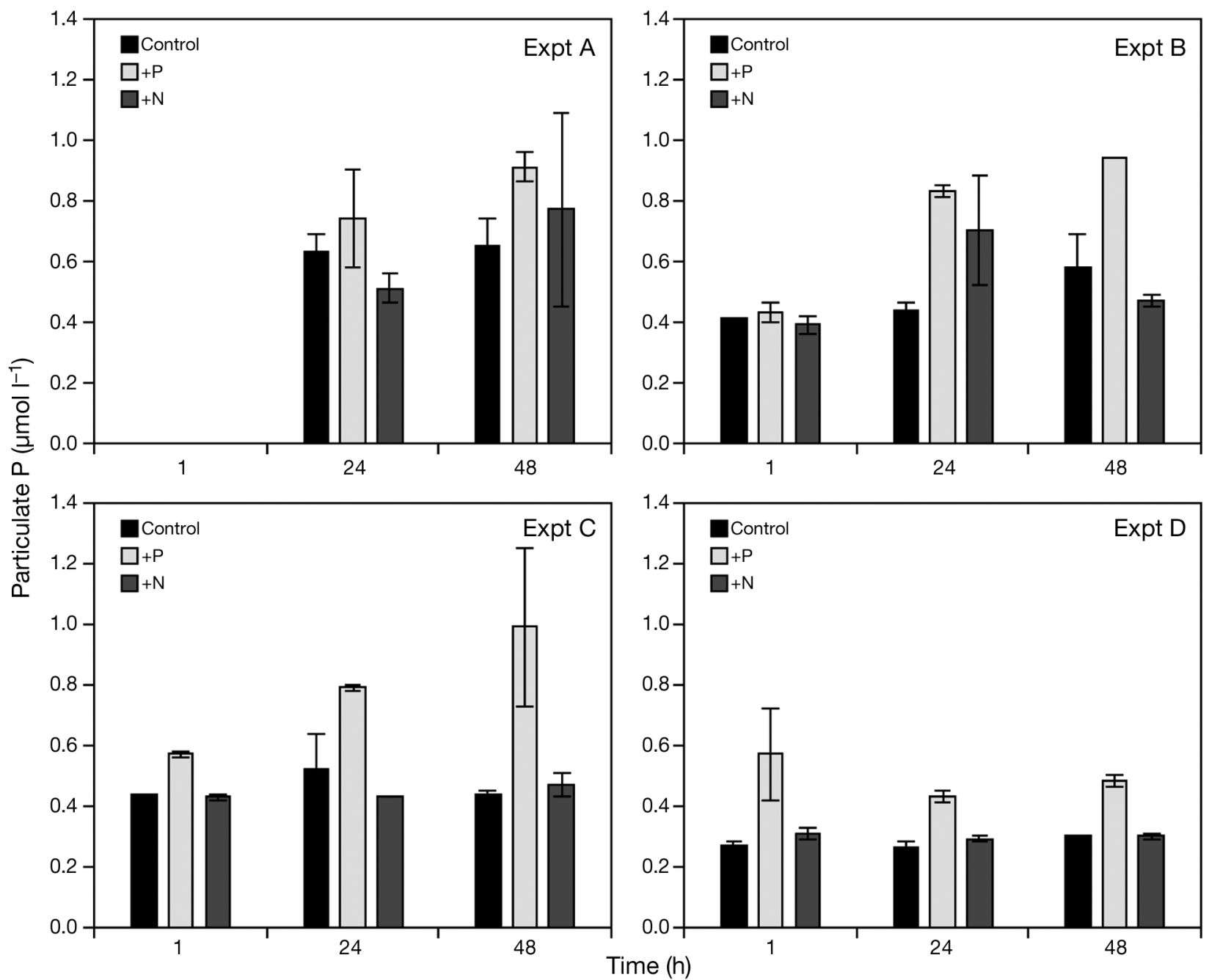

Fig. 3. Average particulate phosphorus concentrations $\left(\mu \mathrm{mol} \mathrm{l}^{-1}\right)$ in the experimental units in Expts A to D during the $48 \mathrm{~h}$ incubations. Error bars denote $\mathrm{SD}, \mathrm{n}=2$ (duplicate treatments). Measurements for Expt $\mathrm{A}$ at Time $1 \mathrm{~h}$ are not available. $+\mathrm{P}$ and $+\mathrm{N}$ indicate the phosphate- and ammonium-addition treatments, respectively

Table 2. Average $( \pm \mathrm{SD})$ soluble reactive phosphorus (SRP) and dissolved inorganic nitrogen (DIN) concentrations $\left(\mu \mathrm{mol} \mathrm{l}^{-1}\right)$ and the average DIN:SRP ratio at the start and end of the experiments. Detection limits (DL) were SRP: $0.05 \mu \mathrm{mol} \mathrm{l}^{-1}, \mathrm{NH}_{4}: 0.25 \mu \mathrm{mol}$ $\mathrm{l}^{-1}, \mathrm{NO}_{2}: 0.06 \mu \mathrm{mol} \mathrm{l} \mathrm{l}^{-1}, \mathrm{NO}_{3}: 0.1 \mu \mathrm{mol} \mathrm{l} \mathrm{l}^{-1}$. NA: measurement not available. $+\mathrm{P}$ and $+\mathrm{N}$ indicate the phosphate- and ammoniumaddition treatments, respectively

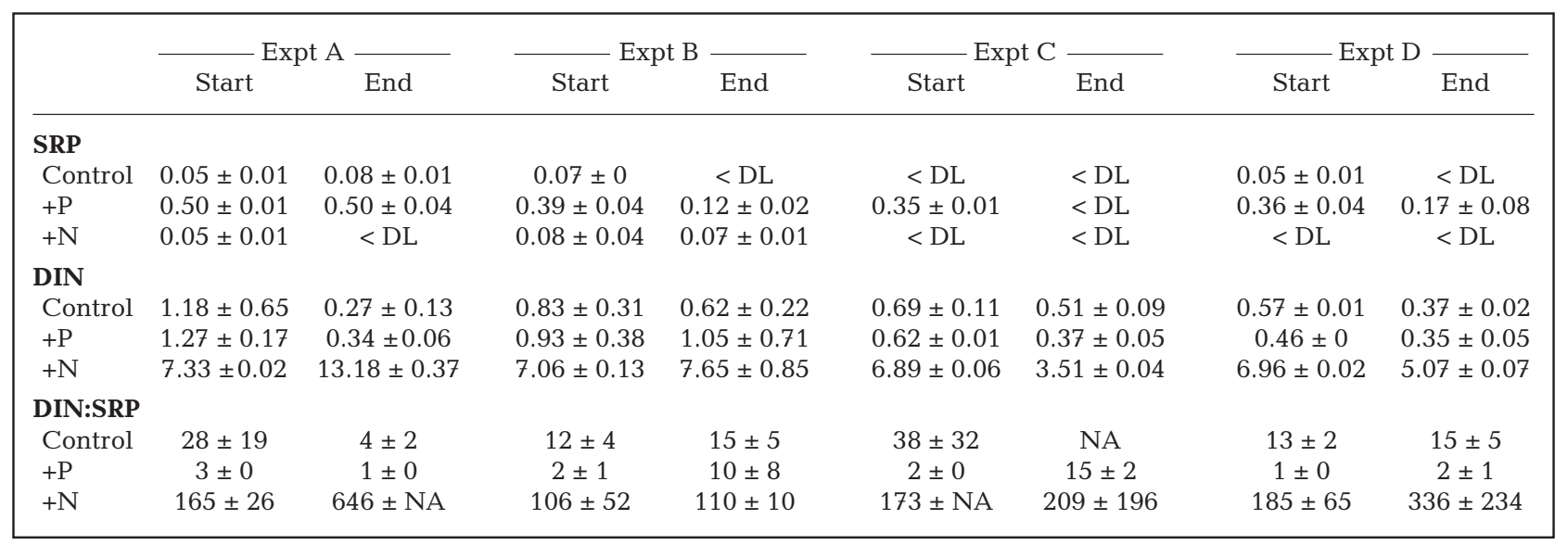




\section{SAPA and APA}

SAPA and APA were on average lowest in Expt A and highest in Expt C (Fig. 4, data for APA not shown). SAPA ranged from 0.02 to $1.18 \mathrm{nmol} \mathrm{MUF} \mathrm{h}^{-1} \mathrm{nmol} \mathrm{P}^{-1}$ during all experiments and was lowest in the $+\mathrm{P}$ treatments. SAPA and APA decreased in all $+\mathrm{P}$ treatments, indicating an alleviation of $\mathrm{P}$ deficiency and a repression of enzyme synthesis by the phosphatase-producing organisms. In contrast, SAPA and APA increased in the Control and $+\mathrm{N}$ treatments during the time of the experiment.

Expt A showed no significant treatment effects, variation in the data was relatively large, and the overall level of SAPA was low (Table 1, Fig. 4). The treatments showed significant effects, and the model interaction term was also significant (Table 1), depicting opposite responses between the $+\mathrm{P}$ treatment and the Control/ $+\mathrm{N}$ treatments during the experiment. Expt $\mathrm{C}$
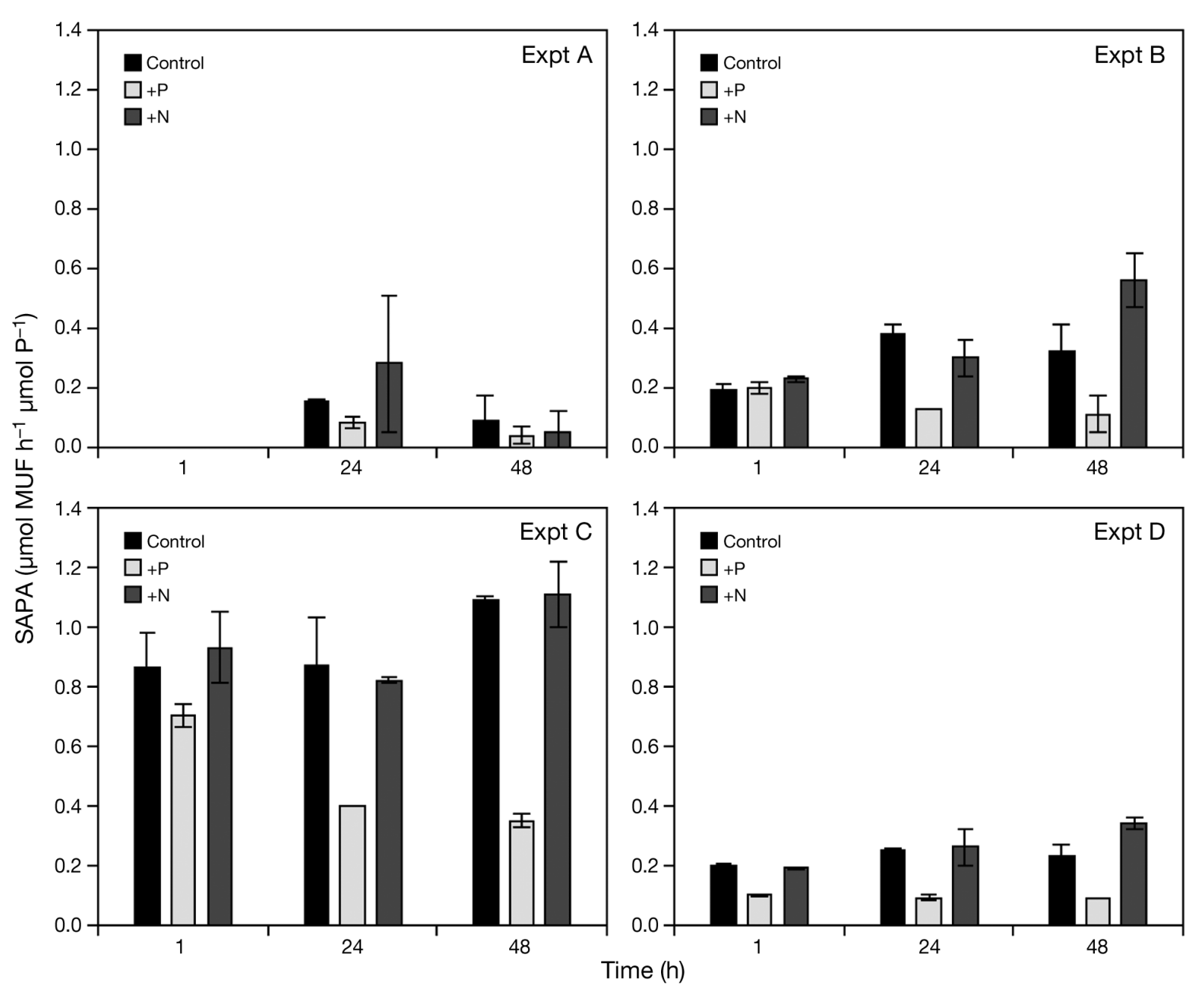

showed a similar pattern in SAPA development to Expt $B$, with a significant treatment effect. The level of SAPA was nevertheless higher, indicating a higher hydrolytic enzyme activity in relation to particulate $\mathrm{P}$ concentrations. This manifested as a significant interaction term in the model (Table 1). Temporal and treatment related patterns of APA were similar to the patterns of SAPA (data not shown).

\section{P turnover times $\left(T_{t}\right)$}

Phosphate addition to the experimental units increased $T_{\mathrm{t}}$ markedly in all experiments (Fig. 5). In Expt $A, T_{t}$ remained high $(>17 \mathrm{~h})$ throughout the experiment in the $+\mathrm{P}$ treatment, indicating an inability of the community to assimilate the added phosphate $\left(0.5 \mu \mathrm{mol} \mathrm{l^{-1 }}\right)$. The $+\mathrm{N}$ treatment showed a decreasing $T_{\mathrm{t}}$, and it was lower compared to the

Fig. 4. Average particulate phosphorus specific alkaline phosphatase activity (SAPA) as $\mu \mathrm{mol}$ MUF $\mathrm{h}^{-1} \mu \mathrm{mol}-\mathrm{P}^{-1}$ in the experimental units in Expts A to D. Error bars denote SD, $\mathrm{n}=2$ (duplicate treatments). Measurements for Expt A at Time $1 \mathrm{~h}$ are not available. $+\mathrm{P}$ and $+\mathrm{N}$ indicate the phosphate- and ammonium-addition treatments, respectively 

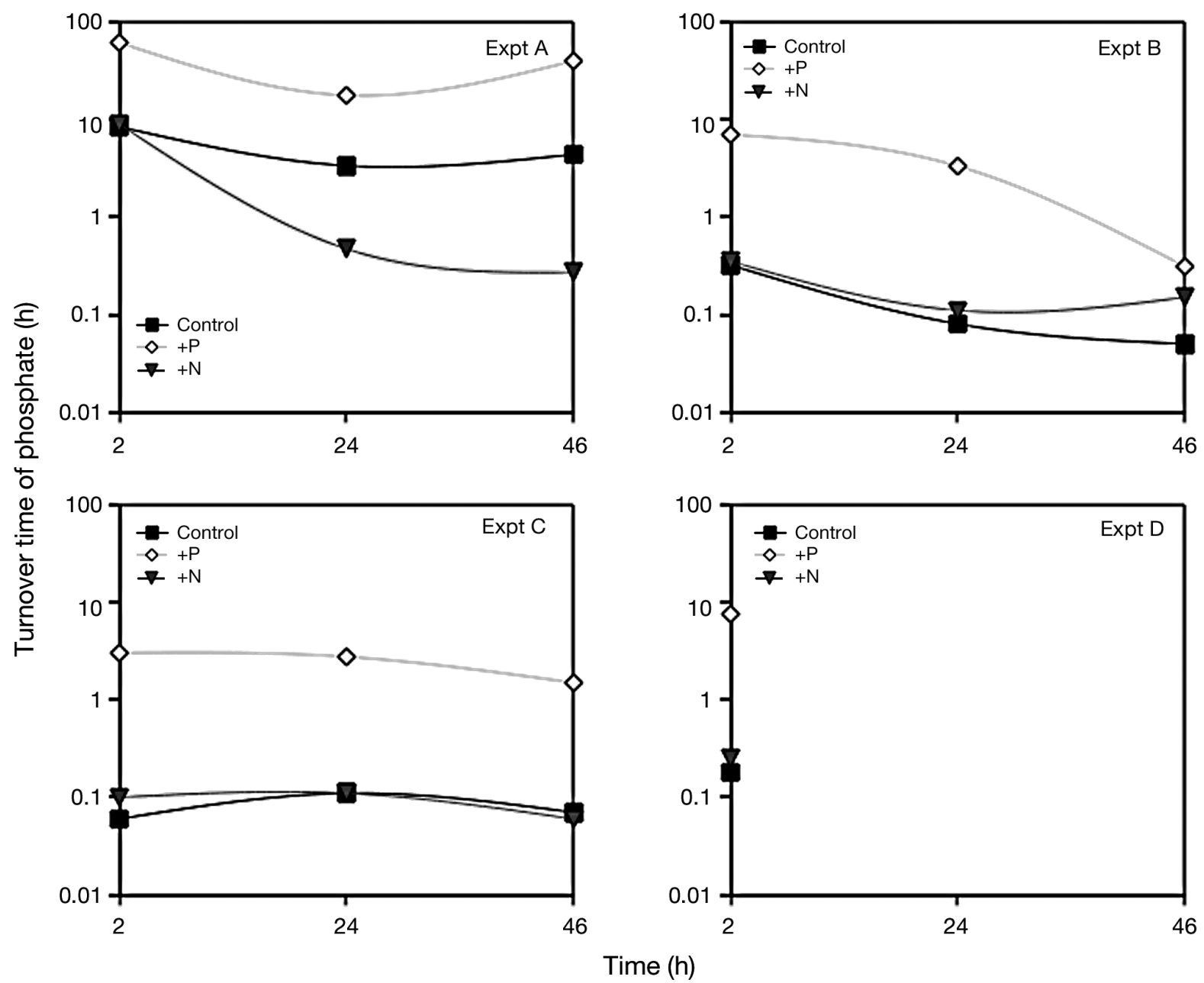

Fig. 5. Average orthophosphate turnover times (h) in the experimental units in Expts A to D. $+\mathrm{P}$ and $+\mathrm{N}$ indicate the phosphateand ammonium-addition treatments, respectively

Control treatment. In Expt $B, T_{t}$ was initially an order of magnitude lower in the Control and $+\mathrm{N}$ treatments compared to the $+\mathrm{P}$ treatment. The Control and $+\mathrm{N}$ treatments showed decreasing $T_{\mathrm{t}}$. The $+\mathrm{P}$ treatment showed a rapidly decreasing $T_{\mathrm{t}}$ after $24 \mathrm{~h}$ to levels comparable to the other treatments. Expt $\mathrm{C}$ showed constantly very fast $T_{\mathrm{t}}$ in the Control and $+\mathrm{N}$ treatments. The $+\mathrm{P}$ treatment showed a steady $T_{\mathrm{t}}$, approximately an order of magnitude faster than for the Control and $+\mathrm{N}$ treatments. Expt D showed similar initial patterns in $T_{\mathrm{t}}$ to the other experiments. Unfortunately, subsequent measurements are not available for Expt D.

\section{Size fractionated phosphate incorporation and specific affinity for phosphate uptake}

The size fractionated relative incorporation of phosphate showed a dominance of incorporation in the
8-20 $\mu \mathrm{m}$ size fraction in all experiments and co-dominance with the $0.2-8 \mu \mathrm{m}$ fraction in Expts $C$ and $D$, particularly in the Control and $+\mathrm{N}$ treatments (Fig. 6). Phosphate addition slightly increased the relative phosphate incorporation in the $>20 \mu \mathrm{m}$ fraction in Expt $\mathrm{B}$ and significantly so in Expts C and D (Table 3). During Expts B, C, and D, which were considered P deficient (see below), the apparent uptake of added phosphate was evident, as approximately $20 \%$ of the added phosphate was taken up and accumulated in the size fraction $>20 \mu \mathrm{m}$. The $>20 \mu \mathrm{m}$ size fraction contained on average $87 \%$ of Aphanizomenon sp. filaments and $89 \%$ of Nodularia spumigena filaments of the total counted filaments. Most of the Anabaena spp. filaments $(87 \%)$ passed the $20 \mu \mathrm{m}$ mesh used in size fractionation, and only $13 \%$ remained in the $>20 \mu \mathrm{m}$ size fraction. Anabaena spp. were nevertheless scarce in all experiments. Of the other large species, Dinophysis acuminata and Oblea rotunda were almost completely retained by the $20 \mu \mathrm{m}$ mesh. Large species other than 

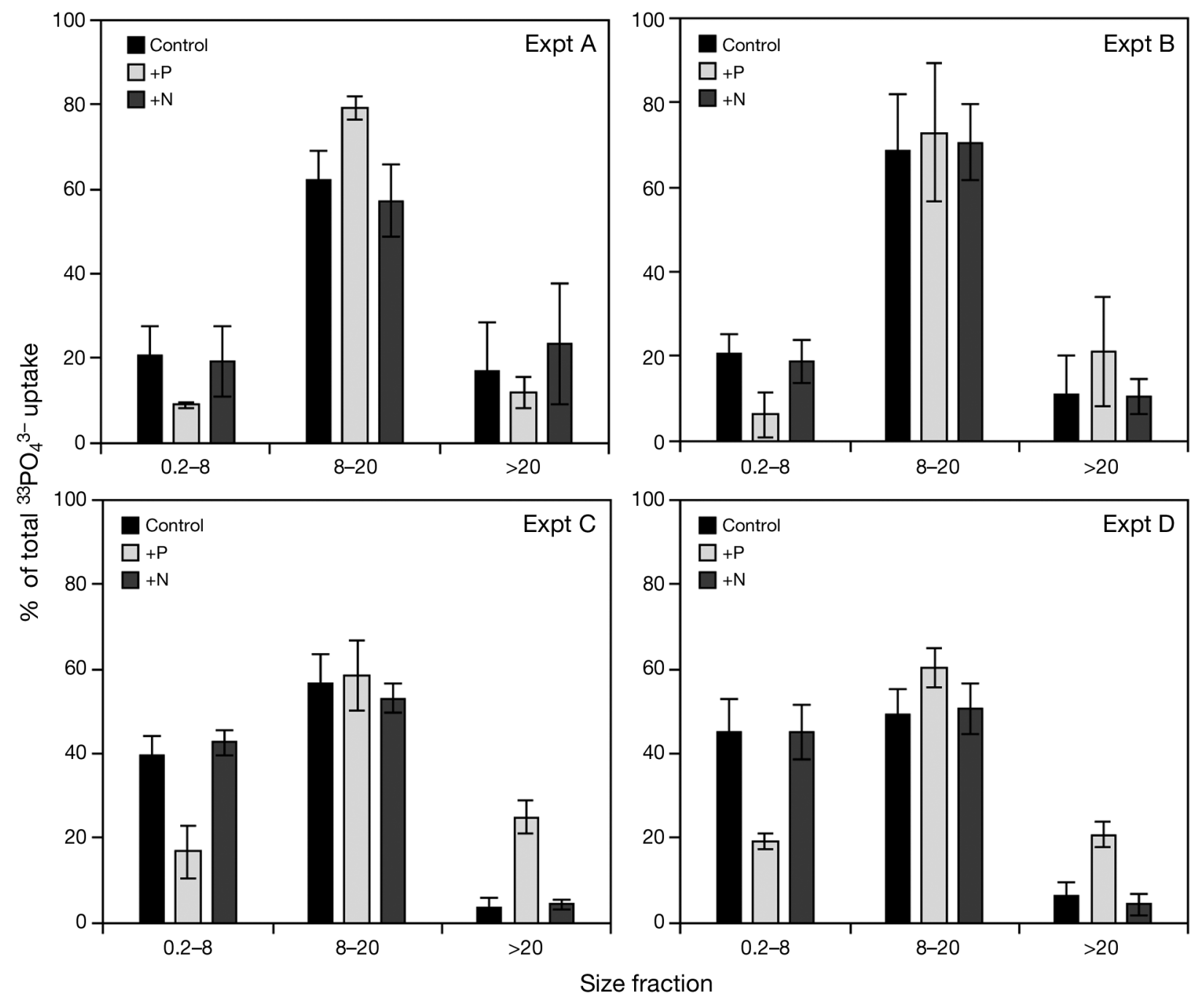

Fig. 6. Average size fractionated uptake of ${ }^{33} \mathrm{PO}_{4}{ }^{3-}$ expressed as the percentage of total uptake for each size fraction $(0.2-8 \mu \mathrm{m}$, 8-20 $\mu \mathrm{m},>20 \mu \mathrm{m})$ in the experiments. Error bars denote SD, n = 3 (measurements at 2, 24 and $48 \mathrm{~h}$ ). $+\mathrm{P}$ and $+\mathrm{N}$ indicate the phosphate- and ammonium-addition treatments, respectively

Table 3. Repeated measures mixed model results for type III tests for fixed effects for the dependent variable describing relative phosphorus uptake by different size fractions. Effect of treatment was tested separately for each fraction. Num df: numerator degrees of freedom, den df: denominator degrees of freedom

\begin{tabular}{|c|c|c|c|c|c|c|c|c|c|c|c|c|c|c|c|c|}
\hline & \multicolumn{4}{|c|}{$\longrightarrow$ Expt $\mathrm{A}$} & \multicolumn{4}{|c|}{$\longrightarrow$ Expt B } & \multicolumn{4}{|c|}{- Expt $\mathrm{C}-$} & \multicolumn{4}{|c|}{ Expt D } \\
\hline & $\begin{array}{c}\text { Num } \\
\text { df }\end{array}$ & $\begin{array}{c}\text { Den } \\
\text { df }\end{array}$ & F & $\mathrm{p}>F$ & $\underset{\mathrm{df}}{\mathrm{Num}}$ & $\begin{array}{c}\text { Den } \\
\text { df }\end{array}$ & $F$ & $\mathrm{p}>F$ & $\underset{\mathrm{df}}{\mathrm{Num}}$ & $\begin{array}{c}\text { Den } \\
\text { df }\end{array}$ & $F$ & $\mathrm{p}>F$ & $\underset{\mathrm{df}}{\mathrm{Num}}$ & $\begin{array}{c}\text { Den } \\
\text { df }\end{array}$ & $F$ & $\mathrm{p}>F$ \\
\hline $8-20 \mu \mathrm{m}$ & 2 & 9 & 12.79 & $<0.01$ & 2 & 8 & 0.09 & 0.91 & 2 & 9 & 0.67 & 0.53 & 2 & 9 & 4.6 & $<0.05$ \\
\hline$>20 \mu \mathrm{m}$ & 2 & 9 & 1.2 & 0.35 & 2 & 8 & 1.5 & 0.28 & 2 & 9 & 79.62 & $<0.01$ & 2 & 9 & 36.89 & $<0.01$ \\
\hline
\end{tabular}

the filamentous Cyanobacteria were present only as minor fractions of the total biomass in the samples.

In Expts $C$ and $D$, the $0.2-8 \mu \mathrm{m}$ fraction in the $+P$ treatments showed a significant decrease in uptake when uptake by the $>20 \mu \mathrm{m}$ size fraction increased
(Table 3). The 8-20 $\mu \mathrm{m}$ fraction in $+\mathrm{P}$ treatments showed only little difference from the other treatments in Expts B and C. However, for Expts A and D, the increase in uptake by this size fraction with phosphate addition was significant (Fig. 6, Table 3). 
The percentage of abiotic adsorption of total uptake ranged from 0.4 to $21.4 \%$, with an average of $2.5 \%$. The highest proportion of abiotic adsorption was encountered in the $+\mathrm{P}$ treatment of Expt $\mathrm{A}$.

The specific affinity for phosphate uptake $(\alpha)$ was lowest during Expt A (Table 4), in all treatments and both studied size fractions. Based on a definition of $\mathrm{P}$ deficiency $\left(\alpha>10 \mathrm{l} \mu \mathrm{mol}-\mathrm{P}^{-1} \mathrm{~h}^{-1}\right)$ by Tanaka et al. (2006), the $0.2-20 \mu \mathrm{m}$ size fraction was P deficient during Expts B, C, and D, and ammonium addition drove these communities into further $\mathrm{P}$ deficiency, depicted by increasing specific affinity for phosphate uptake. $\mathrm{P}$ addition markedly lowered the $\mathrm{P}$ deficiency of both size fractions, as shown by the decrease in the specific affinity for phosphate uptake by an order of magnitude lower than the control and ammonium addition treatments.

\section{ELF}

ELF assays revealed distinct patterns of $\mathrm{P}$ stress between the main bloom-forming species Aphanizomenon sp. and Nodularia spumigena. N. spumigena always had a significantly higher amount of ELFA fluorescent filaments per population than Aphanizomenon sp. (Fig. 7, Table 5). Treatment effects were not significant in Expt A, but were significant in Expt B where both N. spumigena and Aphanizomenon sp. showed decreasing relative amounts of ELFA fluorescent filaments in the $+\mathrm{P}$ treatment. In Expt $\mathrm{C}$, the phosphate addition initially decreased the amount of ELFA fluorescent $N$. spumigena filaments. However, treatment effects were non-significant. Expt D displayed a significant species and treatment interaction term, indicating that the species reacted differently to the nutrient additions. The effect of phosphate addition was generally more pronounced for Aphanizomenon sp. than for $N$. spumigena. Cyanobacterial filaments that displayed ELFA fluorescence always had all cells labeled.

\section{DISCUSSION}

Our aim was to elucidate the effect of altered nutrient supply stoichiometry on phosphate uptake in natural cyanobacterial bloom communities during the generally nutrient depleted bloom period. In our experiments, phosphate addition always increased the particulate $\mathrm{P}$ concentrations and $T_{\mathrm{t}}$ and decreased SAPA and the specific affinity for phosphate uptake. Phosphate addition also decreased the relative amount of ELFA fluorescent filaments of Aphanizomenon sp. and Nodularia spumigena to some degree. Effects of phosphate addition on chl a concentrations were subtle. Ammonium addition treatments responded similarly to the control treatments, with some exceptions. During Expt A, $T_{\mathrm{t}}$ decreased notably with ammonium addition, indicating an increased $P$ turnover with the ammonium addition. The $T_{\mathrm{t}}$ of the control treatments was notably different from Expt A and the rest of the experiments. $T_{\mathrm{t}}$ was initially more than an order of magnitude higher in Expt A than in the other experiments, showing a faster turnover of the $\mathrm{P}$ pool and potentially indicating a more pronounced $\mathrm{P}$ shortage in Expts B, C, and D.

$T_{\mathrm{t}}$ on its own is to be considered a relative index of $\mathrm{P}$ availability and not an estimate of phosphate uptake. Tanaka et al. (2006) suggested that the specific phosphate uptake affinity and/or the specific APA can be used as measures of P deficiency. The specific affinity for phosphate uptake can be seen as an analogue for the clearance rate by phagotrophic organisms: the lower the affinity, the poorer the organism is at competing for a specific resource. The concept of specific affinity is valid when the substrate that is under study is limiting growth, i.e. it is assumed that uptake of the substrate is intimately coupled with growth. If the substrate is not limiting growth, the value of the specific affinity will be an underestimate of the 'true' value because the substrate concentration is beyond the range of linear uptake of the substrate (Thingstad \& Rassoulzadegan 1999). This scenario was probably the case during Expt A, and therefore the values for the specific affinity are lower limits of the true values.

Compared to the control and Naddition treatments, $\mathrm{P}$ addition lowered the average affinity for phosphate uptake by an order of magnitude in most cases. A distinct difference between control treatments was that during Expt A, the specific affinity for phosphate uptake was an order of magnitude lower than for Expts B to D. These
aValues indicate phosphate limitation of the size fractionated community as defined by Tanaka et al. (2006) with values $>101 \mu \mathrm{mol}^{-1} \mathrm{P} \mathrm{h}^{-1}$ indicative of phosphorus deficiency 

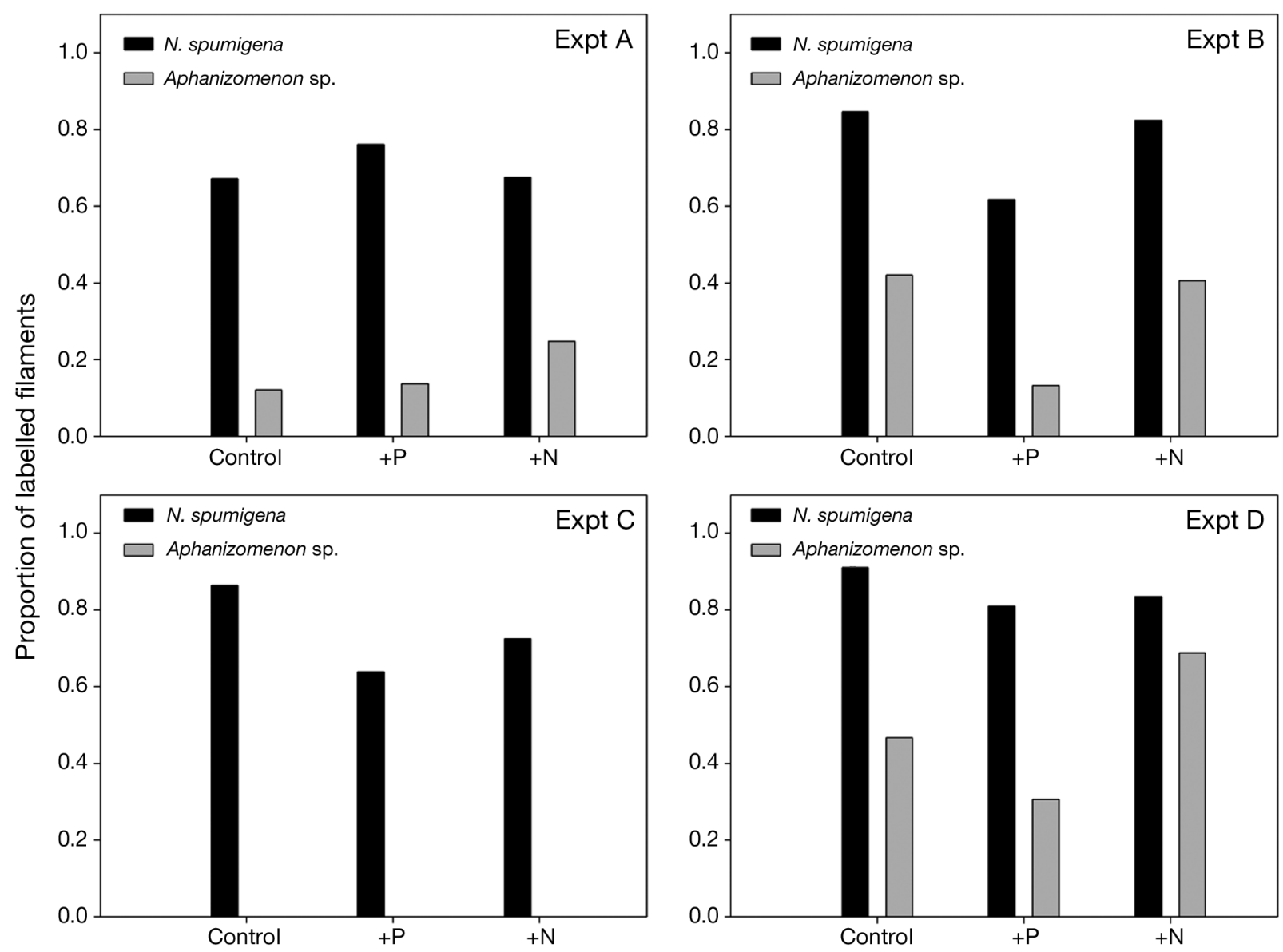

Fig. 7. Nodularia spumigena and Aphanizomenon sp. Relative amount of enzyme-labeled fluorescence (ELF)-labeled filaments of the total population for N. spumigena and Aphanizomenon sp. in all treatments during the experiments. For Expt C, an insufficient amount of Aphanizomenon sp. filaments were present for statistically meaningful presentation. $+\mathrm{P}$ and $+\mathrm{N}$ indicate the phosphate- and ammonium-addition treatments, respectively

Table 5. Repeated measures mixed model results for type III tests for fixed effects for the dependent variable enzyme-labeled fluorescence. Since an insufficient amount of Aphanizomenon sp. filaments were present in Expt C, the species and interaction terms are unavailable. Num df: numerator degrees of freedom, den df: denominator degrees of freedom

\begin{tabular}{|c|c|c|c|c|c|c|c|c|c|c|c|c|c|c|c|c|}
\hline & \multicolumn{4}{|c|}{$\longrightarrow$ Expt $\mathrm{A}$} & \multicolumn{4}{|c|}{ Expt B -} & \multicolumn{4}{|c|}{- Expt $\mathrm{C}-$} & \multicolumn{4}{|c|}{ - Expt D } \\
\hline & $\begin{array}{c}\text { Num } \\
\text { df }\end{array}$ & $\begin{array}{c}\text { Den } \\
\text { df }\end{array}$ & $F$ & $\mathrm{p}>F$ & $\begin{array}{c}\text { Num } \\
\text { df }\end{array}$ & $\begin{array}{c}\text { Den } \\
\text { df }\end{array}$ & F & $\mathrm{p}>F$ & $\underset{\text { df }}{\text { Num }}$ & $\begin{array}{c}\text { Den } \\
\text { df }\end{array}$ & $F$ & $\mathrm{p}>F$ & $\begin{array}{c}\text { Num } \\
\text { df }\end{array}$ & $\begin{array}{c}\text { Den } \\
\text { df }\end{array}$ & $F$ & $\mathrm{p}>F$ \\
\hline Species & 1 & 12 & 47.27 & $<0.01$ & 1 & 12 & 38.34 & $<0.01$ & & & & & 1 & 12 & 73.32 & $<0.01$ \\
\hline Treatment & 2 & 12 & 0.26 & 0.77 & 2 & 12 & 5.41 & 0.02 & 2 & 6 & 1.68 & 0.26 & 2 & 12 & 7.79 & $<0.01$ \\
\hline Interaction & 2 & 12 & 0.55 & 0.59 & 2 & 12 & 0.09 & 0.92 & & & & & 2 & 12 & 6.65 & 0.01 \\
\hline
\end{tabular}

results show that the osmotroph community in Expt A was more P sufficient than the communities in the subsequent experiments. According to Tanaka et al. (2006), values of specific affinity for phosphate uptake $>101 \mu \mathrm{mol}-\mathrm{P}^{-1} \mathrm{~h}^{-1}$ indicate $\mathrm{P}$ deficiency of the community. However, the estimates of the specific phosphate affinity are subject to difficulties in measuring the $\mathrm{P}$ biomass of the osmotroph community. In the present study, we used the particulate P concentrations, sub- jecting the results to error due to the presence of detritus, and thus, a potential underestimation of true values.

The SAPA results further support the observation of a more P sufficient community during Expt A. SAPA was very low in Expt A and initially higher in all other experiments. Phosphate addition decreased SAPA in Expts B to D, in accordance with the specific affinity estimates. APA was determined using $4 \mathrm{ml}$ samples, 
which might cause high variation in the data due to presence of large cyanobacterial aggregates unevenly sampled by such a small volume. However, the data did not show markedly high standard deviation, except during Expt A, when APA was generally low.

$\mathrm{N}$ addition stimulated the turnover of the $\mathrm{P}$ pool during Expt A. SRP concentrations declined to levels below the detection limit by the end of Expt A, even though no marked increase in either chl a nor $\mathrm{P}$ biomass was observed due to initially very low SRP concentrations. The specific affinity for phosphate uptake showed no increase in the $0.2-20 \mu \mathrm{m}$ size fraction, whereas ammonium addition seemed to increase the affinity of the larger size fraction. Compared to the other experiments, the affinities were nevertheless very low. The relatively large $\mathrm{P}$ biomass concentration estimates during Expt A, however, may have caused underestimation of the specific affinities.

Dependent upon the initial conditions of the community (i.e. $\mathrm{P}$ sufficiency or deficiency) phosphate additions increased the relative uptake of phosphate the greatest in the $>20 \mu \mathrm{m}$ size fraction.

During Expt A, a proportionally larger fraction of added phosphate (up to $20 \%$ ) accumulated in particulate form through abiotic adsorption, compared to the average value of $2.5 \%$ during the experiments. Abiotic adsorption of phosphate onto Cyanobacteria-aggregate surfaces might be a significant P storage method in addition to intracellular stores. Abiotic adsorption of phosphate has been noted to occur in filamentous Cyanobacteria and is known to contribute to growth (Sañudo-Wilhelmy et al. 2004, Fu et al. 2005).

The relative amount of filaments showing ELFA fluorescence was always lower for Aphanizomenon sp. Peculiarly, the majority of Nodularia spumigena filaments nevertheless showed ELFA fluorescence in Expt A with very low SAPA and APA. This might be an artifact caused by a relatively small $N$. spumigena population present during Expt A, or evidence for an adaptation to chronically low phosphate concentrations and slow response to changes in environmental conditions (Degerholm et al. 2006). High relative amounts of ELFA fluorescent filaments might also be due to the utilization of the original ELF protocol developed by Gonzaléz-Gil et al. (1998). The original protocol includes an ethanol incubation, which might increase the permeability of the cell membrane. Therefore, the method might also detect intracellular phosphatases (Nedoma et al. 2003). Nedoma et al. (2003) also pointed out the importance of variable time lag in ELFA precipitate formation. Due to this time lag, labeling kinetic studies should be done to determine the suitable incubation time for each environmental sample. The use of a 30 min incubation time in the present study might therefore have underestimated the amount of ELFA fluorescence in our samples.
Furthermore, samples were stored in filtered and autoclaved sea water of which the absolute phosphate concentration was not known. Storage of ELF samples in sea water with low concentrations of phosphate might not stop the formation of ELFA. This would cause an overestimation of ELFA fluorescent filaments (Nedoma et al. 2003). However, since all samples were treated in the same manner, the errors induced by the above methodological caveats are similar in all samples, making the samples comparable to each other.

The results from this short-term experimental study are in general accordance with previous field research. Pulsed phosphate supplies introduced to the surface layer by frontal or coastal upwelling events have been noted to promote blooms of Aphanizomenon sp. (Kononen et al. 1996, Vahtera et al. 2005), and experimental studies have shown a stimulating effect of phosphate addition on $\mathrm{N}_{2}$-fixation (Moisander et al. 2003, 2007). Recently, Nausch et al. (2009) showed that phosphate enrichment of the surface layer by upwelling markedly lowered the C:P ratio of filamentous Cyanobacteria and that uptake of phosphate was intensified most in $\mathrm{P}$ deplete cells occurring at frontal regions. We used non-diluted surface water samples that do not reflect the conditions in upwelling regions; however, they might be more representative of frontal regions where 'old' surface waters with P-starved cells are mixed with the newly upwelled phosphate-rich intermediate waters, reflecting a situation similar to what Nausch et al. (2009) observed.

We experimentally showed that a portion of the added phosphate is directly assimilated into the cyanobacterial size fraction, alleviating $P$ deficiency. In our experiments, no apparent effects on growth (chl a concentrations) could be seen, presumably because the diazotrophic filamentous Cyanobacteria generally have slow growth rates (Lehtimäki et al. 1997, Stolte et al. 2002); phosphate uptake has been noted to be decoupled from growth in phytoplankton (Lean \& Pick 1981). Since ammonium addition did not markedly increase chl a concentrations in any of the experiments in relation to the control treatments, the biomass of non-N-fixing constituents of the plankton community were deemed $\mathrm{P}$ or $\mathrm{N}$ and $\mathrm{P}$ limited. Without a combined $\mathrm{N}$ and $\mathrm{P}$ addition, it is impossible to say whether $\mathrm{P}$ or $\mathrm{N}$ and $\mathrm{P}$ together were the limiting factors. However, during Expt A, ammonium addition markedly decreased phosphate turnover times. This indicates that in our experiments, $\mathrm{N}$ limitation was subordinated to $\mathrm{P}$ limitation. Only when $\mathrm{P}$ was sufficient, in this case accumulated in the organisms as observed in Expt A, did ammonium addition evoke an effect in phosphate turnover times, indicating $\mathrm{P}$ as the dominant limiting factor. The differing responses between experiments are likely due to differing nutritional histories of the 
communities used in the experiments (cf. Nausch et al. 2009) and the diverse nutritional and growth strategies of phytoplankton (Kangro et al. 2007). A longer experiment might have subsequently allowed for an increase in the biomass of filamentous Cyanobacteria (cf. Moisander et al. 2003).

\section{CONCLUSIONS}

It has been stated that the nutrient storage capacity of the bloom-forming and N-fixing Cyanobacteria would be the main strategy for their $\mathrm{P}$ acquisition and that winter phosphate concentrations and cellular $\mathrm{P}$ storage, to a large extent, govern the magnitude of the blooms (Larsson et al. 2001, Janssen et al. 2004). Based on our results, we propose that elevated phosphate concentrations cause a shift of phosphate uptake towards larger plankton size fractions during cyanobacterial blooms, when non-N-fixing species are mainly $\mathrm{N}$ or $\mathrm{N}$ and $\mathrm{P}$ co-deficient. In our experiments, most of the phytoplankton biomass in the $>20 \mu \mathrm{m}$ size fraction, and $>50 \%$ of the entire phytoplankton community wet weight biomass, consisted of $\mathrm{N}$-fixing Cyanobacteria. Elevated phosphate concentrations, caused by a single addition pulse during generally Pdeficient conditions, alleviated the $\mathrm{P}$ deficiency of the phytoplankton community by lowering the specific affinity for phosphate uptake, the P biomass SAPA, and the species-specific expression of APA. This was especially evident for Aphanizomenon sp., and these results are in accordance with previous findings (Degerholm et al. 2006). Ammonium addition did not cause an increase in growth, measured as chl a biomass, but $\mathrm{P}$ addition caused an increase in phosphate uptake, with a relatively greater effect in the $>20 \mu \mathrm{m}$ size fraction dominated by the $\mathrm{N}$-fixing Cyanobacteria.

Acknowledgements. E.V. acknowledges the Maj and Tor Nessling foundation for financing the study. We thank T. Aaltonen, K. Luodekari and P. Maunula for chl a analyses; A. Nurmi and K. Hyvärinen for the nutrient analyses; M. Huttunen for phytoplankton counts; and the technical staff of FIMR and the crew of RV 'Aranda' for hard work during the cruise. We acknowledge the valuable comments made on the manuscript by H. Kuosa.

\section{LITERATURE CITED}

> Degerholm J, Gundersen K, Bergman B, Söderbäck E (2006) Phosphorus-limited growth dynamics in two Baltic Sea Cyanobacteria, Nodularia sp. and Aphanizomenon sp. FEMS Microbiol Ecol 58:323-332

Engström J, Viherluoto M, Viitasalo M (2001) Effects of toxic and non-toxic Cyanobacteria on grazing, zooplanktivory and survival of the mysid shrimp Mysis mixta. J Exp Mar Biol Ecol 257:269-280
Fu FX, Zhang Y, Leblanc K, Sanudo-Wilhelmy SA, Hutchins DA (2005) The biological and biogeochemical consequences of phosphate scavenging onto phytoplankton cell surfaces. Limnol Oceanogr 50:1459-1472

González-Gil S, Keafer BA, Jovine RVM, Aguilera A, Lu S, Anderson DM (1998) Detection and quantification of alkaline phosphatase in single cells of phosphorus-starved marine phytoplankton. Mar Ecol Prog Ser 164:21-35

Granéli E, Wallström K, Larsson U, Granéli W, Elmgren R (1990) Nutrient limitation of primary production in the Baltic Sea area. Ambio 19:142-151

Grasshoff K, Ehrhardt M, Kremling K (eds) (1983) Methods of seawater analysis. 2nd revised and extended edn. Verlag Chemie, Weinheim

Haapala J (1994) Upwelling and its influence on nutrient concentration in the coastal area of the Hanko peninsula, entrance of the Gulf of Finland. Estuar Coast Shelf Sci 38: 507-521

- Hambright KD, Zohary T, Easton J, Azoulay B, Fishbein T (2001) Effects of zooplankton grazing and nutrients on the bloom-forming, $\mathrm{N}_{2}$-fixing cyanobacterium Aphanizomenon in Lake Kinneret. J Plankton Res 23:165-174

HELCOM (Helsinki Commission) (1983) Guidelines for the Baltic monitoring programme for the second stage. Balt Sea Environ Proc 12

HELCOM (1988) Guidelines for the Baltic monitoring programme for the third stage; part D. Biological determinands. Balt Sea Environ Proc 27D

Janssen F, Neumann T, Schmidt M (2004) Inter-annual variability in Cyanobacteria blooms in the Baltic Sea controlled by wintertime hydrographic conditions. Mar Ecol Prog Ser 275:59-68

Kangro K, Olli K, Tamminen T, Lignell R (2007) Species-specific responses of a Cyanobacteria-dominated phytoplankton community to artificial nutrient limitation: a Baltic Sea coastal mesocosm study. Mar Ecol Prog Ser 336:15-27

Kivi K, Kaitala S, Kuosa H, Kuparinen J and others (1993) Nutrient limitation and grazing control of the Baltic plankton community during annual succession. Limnol Oceanogr 38:893-905

Kononen K, Lahdes EO, Grönlund L (1993) Physiological and community responses of summer plankton to nutrient manipulation in the Gulf of Finland (Baltic Sea) with special reference to phosphorus. Sarsia 78:243-253

Kononen K, Kuparinen J, Mäkelä K, Laanemets J, Pavelson J, Nõmmann S (1996) Initiation of Cyanobacterial blooms in a frontal region at the entrance to the Gulf of Finland, Baltic Sea. Limnol Oceanogr 41:98-112

> Kuosa H, Autio R, Kuuppo P, Setälä O, Tanskanen S (1997) Nitrogen, silicon and zooplankton controlling the Baltic spring bloom: an experimental study. Estuar Coast Shelf Sci 45:813-821

> Laanemets J, Lilover MJ, Raudsepp U, Autio R, Vahtera E, Lips I, Lips U (2006) A fuzzy logic model to describe the Cyanobacteria Nodularia spumigena blooms in the Gulf of Finland, Baltic Sea. Hydrobiologia 554:31-45

Larsson U, Hajdu S, Walve J, Elmgren R (2001) Baltic Sea nitrogen fixation estimated from the summer increase in upper mixed layer total nitrogen. Limnol Oceanogr 46:811-820

Lean DRS, Pick FR (1981) Photosynthetic response of lake plankton to nutrient enrichment: a test for nutrient limitation. Limnol Oceanogr 26:1001-1019

> Lehtimäki J, Moisander P, Sivonen K, Kononen K (1997) Growth, nitrogen fixation and nodularin production by two Baltic Sea Cyanobacteria. Appl Environ Microbiol 63: $1647-1656$ 
Lignell R, Seppälä J, Kuuppo P, Tamminen T, Andersen T, Gismervik I (2003) Beyond bulk properties: responses of coastal summer plankton communities to nutrient enrichment in the northern Baltic Sea. Limnol Oceanogr 48: 189-209

Lips I, Lips U (2008) Abiotic factors influencing Cyanobacterial bloom development in the Gulf of Finland (Baltic Sea). Hydrobiologia 614:133-140

Moisander P, Rantajärvi E, Huttunen M, Kononen K (1997) Phytoplankton community in relation to salinity fronts at the entrance to the Gulf of Finland, Baltic Sea. Ophelia 46: 187-203

Moisander PH, Steppe TF, Hall NS, Kuparinen J, Paerl HW (2003) Variability in nitrogen and phosphorus limitation for Baltic Sea phytoplankton during nitrogen-fixing Cyanobacterial blooms. Mar Ecol Prog Ser 262:81-95

Moisander PH, Paerl HW, Dyble J, Sivonen K (2007) Phosphorus limitation and diel control of nitrogen-fixing Cyanobacteria in the Baltic Sea. Mar Ecol Prog Ser 345: 41-50

Myrberg K, Andrejev O (2003) Main upwelling regions in the Baltic Sea - a statistical analysis based on three-dimensional modelling. Boreal Environ Res 8:97-112

- Nausch M, Nausch G, Wasmund N, Nagel K (2008) Phosphorus pool variations and their relation to Cyanobacteria development in the Baltic Sea: a three year study. J Mar Syst 71:99-111

Nausch M, Nausch G, Lass HU, Mohrholz V, Nagel K, Siegel H, Wasmund N (2009) Phosphorus input by upwelling in the eastern Gotland Basin (Baltic Sea) in summer and its effects on filamentous Cyanobacteria. Estuar Coast Shelf Sci 83:434-442

Nedoma J, Strosjová A, Vrba J, Komárková J, Slmek K (2003) Extracellular phosphatase activity of natural plankton studied with ELF97 phosphate: fluorescence quantification and labelling kinetics. Environ Microbiol 5:462-472

Olenina I, Hajdu S, Edler L, Andersson A and others (2006) Biovolumes and size-classes of phytoplankton in the Baltic Sea. Balt Sea Environ Proc 106

Pavelson J, Laanemets J, Kononen K, Nõmmann S (1997) Quasi-permanent density front at the entrance to the Gulf of Finland: response to wind forcing. Cont Shelf Res 17: 253-265

Petterson K (1980) Alkaline phosphatase activity and algal surplus phosphorus as phosphorus-deficiency indicators in Lake Erken. Arch Hydrobiol 89:54-87

Sañudo-Wilhelmy SA, Tovar-Sanchez A, Fu FX, Capone DG, Carpenter EJ, Hutchins DA (2004) The impact of surfaceadsorbed phosphorus on phytoplankton Redfield stoichiometry. Nature 432:897-901

Editorial responsibility: Daniel Vaulot, Roscoff, France
Sellner KG, Olson MM, Kononen K (1994) Copepod grazing in a summer Cyanobacteria bloom in the Gulf of Finland. Hydrobiologia 292-293:249-254

Smith VH (1983) Low nitrogen to phosphorus ratios favor dominance by blue-green algae in lake phytoplankton. Science 221:669-671

Stal LJ, Staal M, Villbrandt M (1999) Nutrient control of Cyanobacterial blooms in the Baltic Sea. Aquat Microb Ecol 18:165-173

Stolte W, Karlsson C, Carlsson P, Granéli E (2002) Modeling the increase of nodularin content in Baltic Sea Nodularia spumigena during stationary phase in phosphorus-limited batch cultures. FEMS Microbiol Ecol 41:211-220

> Stolte W, Balode M, Carlsson P, Grzebyk D and others (2006) Stimulation of nitrogen-fixing Cyanobacteria in a Baltic Sea plankton community by land-derived organic matter or iron addition. Mar Ecol Prog Ser 327:71-82

Suikkanen S, Laamanen M, Huttunen M (2007) Long-term changes in summer phytoplankton communities of the open northern Baltic Sea. Estuar Coast Shelf Sci 71: 580-592

> Tamminen T, Andersen T (2007) Seasonal phytoplankton nutrient limitation patterns as revealed by bioassays over Baltic Sea gradients of salinity and eutrophication. Mar Ecol Prog Ser 340:121-138

Tanaka T, Henriksen P, Lignell R, Olli K, Seppälä J, Tamminen T, Thingstad TF (2006) Specific affinity for phosphate uptake and specific alkaline phosphatase activity as diagnostic tools for detecting phosphorus-limited phytoplankton and bacteria. Estuaries Coasts 29(6B): 1226-1241

Thingstad FT, Rassoulzadegan F (1999) Conceptual models for the biogeochemical role of the photic zone microbial food web, with particular reference to the Mediterranean Sea. Prog Oceanogr 44:271-286

> Thingstad FT, Skjoldal EF, Bohne RA (1993) Phosphorus cycling and algal-bacterial competition in Sandsfjord, western Norway. Mar Ecol Prog Ser 99:239-259

Utermöhl H (1958) Zur Vervollkommnung der quantitativen Phytoplankton-Methodik. Mitt Int Ver Theor Angew Limnol 9:1-38

Vahtera E, Laanemets J, Pavelson J, Huttunen M, Kononen K (2005) Effect of upwelling on the pelagic environment and bloom-forming Cyanobacteria in the western Gulf of Finland, Baltic Sea. J Mar Syst 58:67-82

Wasmund N, Nausch G, Matthäus W (1998) Phytoplankton spring blooms in the southern Baltic Sea-spatio-temporal development and long-term trends. J Plankton Res 20: 1099-1117

Submitted: October 16, 2008; Accepted: January 23, 2010 Proofs received from author(s): April 23, 2010 